\title{
Taxation of the Public Sector in Poland
}

\author{
ANDRZEJ HUCHLA*
}

A definitive explanation of "public sector" does not exist in the Polish law. However, there are some provisions which may suggest the legal meaning of this term. They are related first of all to European acts on public procurement - mostly Directive 2014/24/EU of the European Parliament and of the Council of 26 February 2014 on public procurement and repealing Directive 2004/18/EC ${ }^{1}$, but not only repeating their wordings.

Act of 29 January 2004 - Law on public procurement ${ }^{2}$, according to art $3 \sec 1$, should be applied for contracting by (among others):

- public finance sector bodies,

- other state units without legal personality

- other legal persons established for the specific purpose of meeting needs in the general interest, not having an industrial or commercial character, if financed in more than $50 \%$ or managed by bodies mentioned above and if it does not act in the ordinary competitive market.

The most characteristic seems to be pointing to the public finance sector bodies as the main scope of relevant subjects. Therefore, "public sector" and "public finance sector" aren't identical ${ }^{3}$. Following art 9 of the Act of 27 August 2009 on public finance ${ }^{4}$, the public finance sector includes: public governance bodies, local government units, budgetary entities, selfgovernment budgetary establishments, budgetary institutions, state agencies and funds, some institutions ruled by special laws (public high schools, the Polish Academy of Sciences, cultural institutions etc.) - except enterprises, research institutes, banks and commercial companies. Though this list is relatively clear, some doubts on qualifying into the public finance sector still remain 5 .

The, so declared public, sector taken as a whole is not a subject of any special rules on taxation in Poland. Acts of tax law even don't use the term "public sector" and there is no system of taxation of the public sector. Therefore, its position in the sphere of taxation must be analyzed through detailed provisions of each tax separately.

DOI: $10.1515 /$ wrlae-2015-0056

* PhD in Law, Assistant Professor at the Chair of Financial Law, Faculty of Law, Administration and Economics, University of Wrocław; andrzej.huchla@uwr.edu.pl

${ }^{1}$ OJ L 94 of 28 March 2014, 65.

2 Dziennik Ustaw - Official Journal of Laws of the Republic of Poland (hereinafter: Dz. U.) 2017, item 1579.

${ }^{3}$ Cezary Kosikowski, Sektor finansów publicznych (Wolters Kluwer Polska, Dom

Wydawniczy ABC 2006) 25.

${ }^{4}$ Dz. U. 2016, item 1870 with later changes.

${ }^{5}$ Kosikowski (n 3) 19. 
The first evident example with reference to public sector can be found in the Act of 11 March 2004 on goods and services tax ${ }^{6}$ (Polish version of VAT). Subject of the tax are individuals and organisational units, irrespective of their legal form - among others legal persons and organisational units without legal personality (art 151) of this Act). Such an expression, often used in different acts of tax law, means the widest scope of subjects to be taxed. However, in the same Act there are additional conditions, important for public sector bodies. First, taxpayers should perform their economic activity independently (art $15 \mathrm{sec} 1$ in fine). Second, public governance organs and their offices are not regarded as taxpayers in respect of activities in carrying out their statutory functions, excluding transactions of civil law (art $15 \mathrm{sec} 6$ ). All this is consistent with art $13 \mathrm{sec} 1$ and 2 of Council Directive 2006/112/EC of 28 November 2006 on the common system of value added tax ${ }^{7}$.

Both of these conditions were analyzed by courts. The most characteristic were cases of the Municipality (City) of Wrocław.

Shortly after introducing the tax on goods and services (in middle 1990-ties) Wrocław did not tax numerous transactions of selling of the municipal property, considering them as public activity, executing independently, but not on their own account and for inhabitants' needs. The Administrative Court of the Voivodship in Wrockaw, in the decision of 10 November $1999^{8}$, decided that such deals are part of the common formula of taxation and there is no legal reason to apply any exemptions. At that time tax provisions were different, but similar to present, so the conclusion remains fully actual and nowadays even quite unquestionable.

In recent years, one important solution to this problem was passed by the Court of Justice of the European Union. The question - referring to the case of the Municipality of Wrocław - was if a budgetary entity could be a taxpayer of the tax on goods and services. According to art 11 of the Act on public finance, budgetary entities are state or municipal units without legal personality, fully dependent on the municipality in the organizational and financial spheres. Particularly they do not have their own revenues and do not have their own expenditures - they are both directly revenues and expenditures of relevant budget, so also of the state or the relevant municipality.

In the judgement of The Grand Chamber of the Court of 29 September $2015^{9}$ answer was that because taxable activity should be independent, such entities must not be considered as subjects of this tax: "art 9 sec 1 of Council Directive 2006/112/EC of 28 November 2006 on the common system of value added tax must be interpreted as meaning that bodies governed by public law, such as the municipal budgetary entities at issue in the main proceedings, cannot be regarded as taxable persons for the

\footnotetext{
${ }^{6}$ Dz. U. 2017, item 1221.

${ }^{7}$ OJ L 347 of 11 December 2006, 1.

${ }^{8}$ I SA/Wr 1697/99, http://orzeczenia.nsa.gov.pl/doc/35FDF9BE0E (accessed 1 December 2016).

${ }^{9}$ C 276/14, EU:C:2015:635,

http://curia.europa.eu/juris/document/document.jsf;jsessionid=9ea7d0f130d66f85775f87c1 4b6d8206d0eb0835a797.e34KaxiLc3eQc40LaxqMbN4Pah8Me0?text=\&docid=168801\&p ageIndex $=0 \&$ doclang $=$ EN\&mode $=1$ st \& dir $=\& o c c=$ first $\&$ part $=1 \&$ cid $=58846($ accessed 10 September 2017).
} 
purposes of value added tax in so far as they do not satisfy the criterion of independence set out in that provision". So it is the municipality itself who is the taxpayer in connection with transactions realized through budgetary entities.

The sentence was soon implemented into Polish law. The Act of 5 September 2016 on special principles of settlement of tax on goods and services and reimbursement of public funds allocated for the implementation of projects financed with funds from the European Union budget, or from Member States of the European Free Trade Agreement, by local governments ${ }^{10}$, fully confirmed the Court's position. According to art 3 and 4 of this Act, self governments must undertake settlements of the tax on goods and services together with their organizational units at the very latest by 1 of January 2017.

Regarding this sentence the situation of "self-government budgetary establishments" (another form of public sector units, settled in arts 14-17 of the Act on public finance) is still unclear. There also do not have legal personality, but are more independent than budgetary entities. First of all they execute their activity (in the municipal public sphere only, such as public transport, maintaining of municipal apartments, roads, cemeteries and greenery and some other functions) covering the expenses by revenues gained for their services and allowed additional grants. That's why they were usually treated as taxpayers. However, one decision of the Supreme Administrative Court of 26 October $2015^{11}$ has accepted the municipality's right of deduction of the tax paid in respect of the investment transferred for budgetary establishment, when such a possibility is usually characteristic for homogeneous taxpayers only. All these remarks were mentioned in the explanatory statement to the bill of The Act on special principles of settlement... ${ }^{12}$. Therefore this Act concerns all municipal organizational units listed in the art 2 point 1 of this Act - both budgetary entities and budgetary establishments, as well as offices of self governments.

Serious doubts still remain on taxation of state budgetary entities (staying out of the Act on special principles of settlement...). Their formal situation as units of the public finance sector is very similar to the municipal entities, but relations with superior subjects or even the state itself may be much more complicated because of expanded structure of state public bodies. On the one hand financial and organizational dependence of state budgetary entities fulfils all criteria of tax exclusion; on the other hand lack of proper provisions may suggest their different position. The same question may apply to "budgetary institutions"; state legal persons with their financial status similar to self-government budgetary establishments (art 24-28 of the Act on public finance).

So, finally, the public units are taxed not only according to the general construction of the goods and services tax - which creates important subjective exclusion. The Act on special principles of settlement... was

\footnotetext{
${ }^{10}$ Dz. U. 2016, item 1888 with later changes.

${ }^{11}$ I FPS 4/15, http://orzeczenia.nsa.gov.pl/doc/22A56560C6 (accessed 10 September 2017).

12 Parliamentary paper of the Sejm of the VIII term, no 709, http://orka.sejm.gov.pl/Druki8ka.nsf/0/CA2F4A36CA6431ADC1257FEE0040CD59/\%24F ile/709.pdf (accessed 10 September 2017).
} 
declared $^{13}$ as specific, special provision, supplementary to the Act on goods and services.

In the Corporate Income Tax, taxpayers are legal persons and organizational units without legal personality (art 1 of the Act of 15 February 1992 on corporate income $\operatorname{tax}^{14}$ ). However, there are numerous exempted subjects, mostly from the public sector and from the public finance sector: among others the State Treasury, self-governments, state agencies and funds, the Polish National Bank, budgetary entities (art 6 of this Act).

Others (not listed as above) should be taxed normally. Some of them can stay out of taxation, if their activity regards to public utility. Article 17 of the same Act (named "Objective exemptions") introduces special settlement of the profit (income) accounts - free of tax is the amount of the profit or its part spent for statutory public purposes. The most important regulation (art $17 \mathrm{sec} 1$ point 4) concerns incomes of the organizational units of: science, education, culture, physical culture and sport, environmental protection, supporting social initiatives for the construction of roads and telecommunications network in rural areas and rural water supply, charity, health service, social assistance, professional and social rehabilitation of disabled, worship. Some of them (like public high schools, research institutes, museums, public health service units) are, once more, public and public finance bodies; others (like societies, foundations, sport clubs, private schools and high schools) usually use to be private subjects. The tax privilege from the art 17 depends on many additional details and conditions. The exclusion does not cover, with subjective exceptions, incomes from some kinds of commercial activity, such as selling tobacco, alcohol, electronic equipment (art $17 \mathrm{sec} 1 \mathrm{a}$ ). Not excluded at all are incomes of state or municipal enterprises, cooperatives and companies, as well as self-government budgetary establishments and other organizational units without legal personality if the object of their business is to satisfy the needs of the public indirectly related to environmental protection in the following areas: water supply and sewage, waste water treatment, landfills and municipal waste and transport (art $17 \mathrm{sec} 1 \mathrm{c}$ ).

The unit must produce and keep the tax rolls and declare the relevant statutory purpose of expenditures in proper tax returns. There is no time limit for spending the exempted income, but its assignment other than declared causes adding of such a quote to the present income and tax assessment $^{15}$ (art $17 \mathrm{sec}$ 6). Therefore, irrespective on the individual situation, all these subjects are called taxpayers.

All these provisions are undoubtedly the most detailed tax regulation of the public sector's tax status. According to them, typical public bodies are practically not taxed ${ }^{16}$.

In real estate taxes (real property tax, land tax, forest tax) there are also listed subjects exempted from taxation. All these provisions: art $7 \sec 2$

\footnotetext{
13 ibid.

${ }^{14}$ Dz. U. 2016, item 1454 with later changes.

${ }^{15}$ For more details see Adam Mariański in Włodzimierz Nykiel, Adam Mariański (eds) Komentarz do ustawy o podatku dochodowym od osób prawnych 2015 (ODDK 2015) 846853.

${ }^{16}$ Rafał Golat, Opodatkowanie działalności kulturalnej (Dom Wydawniczy ABC 2005) 69.
} 
of the Act of 12 January 1991 on local taxes and fees ${ }^{17}$, art $12 \sec 2$ of the Act of 15 November 1984 on land tax ${ }^{18}$, art $7 \mathrm{sec} 2$ of the Act of 30 October 2002 on forest $\operatorname{tax}^{19}$ are identical. Free of these taxes are (among others) schools, high schools, research institutes.

First, it expresses a clear intention of the tax relief of some public bodies. (Though the exemption concerns also parallel private units - hereby different forms of property are treated equally -such private units are not representative for those spheres of activity). Second, this tax preference relates to only a small part of public sector bodies. The essential explanation is that all these taxes are revenues of the municipalities, when both the goods and services tax and the corporate income tax are revenues of the state budget. So the tax amounts are received from private subjects, but also from the State, voivodships, districts being owners of real estate placed in the area of the municipality. Only in the land tax is the State Treasury personally freed of tax (art 3a point lof the Act on land tax). When state or self-government property is possessed by other subjects, they are taxpayers (immovable property in direct disposal of municipalities themselves are obviously free of tax).

State Treasury and self-governments are exempted from two smaller tax burdens, also municipalities` receipts.

In the tax on civil law transactions both of these public subjects are pointed by simple and direct exemptions, as well as one only state agency (art 8 points 4,5 and 8 of The Act of 9 September 2000 on the tax on civil law transactions ${ }^{20}$ ).

Self-governments and budgetary entities are also directly exempted of the most common fee - stamp duty, another municipality budgetary revenue (art 7 points 2 and 3 of the Act of 16 November 2006 on stamp duty $\left.^{21}\right)$.

This short review of the main tax regulations relating to public sector bodies shows that, in different tax acts, different solutions may by binding at law. Actually they all attempt to introduce special tax exemptions, but with a substantial variety of legal constructions and -most importantly - of the subjective scope of exempted bodies. Perhaps it is possible to prove that there is some general trend not to tax public sector subjects. However, relevant provisions are fragmentary and incoherent. The most difficult situation seems to be in the tax on goods and services. Even clear regulation of some detailed questions may cause serious doubts as to the legal position of similar (but not settled so directly) spheres - like state budgetary entities as taxpayers of this tax. Other tax provisions usually do not provoke important disputes.

\footnotetext{
${ }^{17}$ Dz. U. 2017, item 1785 with later changes.

${ }^{18}$ Dz. U. 2016, item 617 with later changes.

${ }^{19}$ Dz. U. 2017, item 1821.

${ }^{20}$ Dz. U. 2017, item 1150.

${ }^{21}$ Dz. U. 2016, item 1827 with later changes.
} 


\section{References}

Golat Rafał, Opodatkowanie działalności kulturalnej (Dom Wydawniczy ABC 2005)

Kosikowski Cezary, Sektor finansów publicznych (Wolters Kluwer Polska, Dom Wydawniczy ABC 2006)

Nykiel Włodzimierz, Mariański Adam (eds), Komentarz do ustawy o podatku dochodowym od osób prawnych 2015 (ODDK 2015) 